\title{
Five Pack
}

National Cancer Institute

\section{Source}

National Cancer Institute. Five Pack. NCI Thesaurus. Code C78777.

A product containing five individual units. 